\title{
Korupsi di Badan Usaha Milik Negara Khususnya Perusahaan Perseroan: Suatu Kajian atas Makna Kekayaan Negara yang Dipisahkan dan Keuangan Negara
}

\author{
Ridwan Khairandy \\ Fakultas Hukum Universitas Islam Indonesia Yogyakarta \\ ridwankhairandy@fh.uii.ac.id
}

\begin{abstract}
This article seek to discuss the concept of the state's properties which are included in the state enterprises (BUMN), especially those which are in the form limited liability companies (Persero). From legal perspective, state's properties which are placed in a limited liability companies are separated properties. The inclusion of such properties in a limited liability company brings about a legal consequence, namely, such properties are then legally belong to the company instead of the state. A limited liability company is an independent entity, and hence, physically, the said state's properties are then deemed as the share. It suffices to conclude therefore, that the state can not in any way in possession of the company as a whole, but rather merely on the limited amount of share.
\end{abstract}

Keywords: State Enterprise, Limited Liability Company, separated state's properties.

\section{Pendahuluan}

Di tengah upaya penyidikan dan penuntutan serta pengadilan oleh aparat penegak hukum terhadap kasus korupsi di berbagai BUMN, khususnya Perusahaan Perseroan (Persero) yang begitu gencar, ternyata menimbulkan banyak kritik. Aparat penegak hukum seringkali dikatakan tidak memahami konsep badan hukum, seperti Perseroan Terbatas (PT) atau Perusahaan Perseroan (Persero).

Juga tidak dipahami benar apa konsekuensi yuridis penyertaan modal oleh negara dalam bentuk kekayaan negara yang dipisahkan dan Badan Usaha Milik Negara (BUMN). Akibatnya, tindakan aparat untuk memberantas 
korupsi di BUMN ternyata bertentangan UU No. 40 Tahun 2007 tentang Perseroan Terbatas (dahulu UU No. 1 Tahun 1995 tentang Perseroan Terbatas) dan UU No. 19 Tahun 2003 tentang Badan Usaha Milik Negara yang menjadi dasar eksistensi dan kegiatan perusahaan dimaksud.

\section{Korporasi sebagai Badan Hukum}

BUMN, khususnya Persero pada dasarnya adalah sebuah korporasi, sebuah badan usaha berbadan hukum yang bertujuan untuk mencari keuntungan. Dengan memahami makna dan konsekuensi badan hukum, akan didapat pemahaman yang utuh tentang Persero.

Pada dasarnya badan hukum adalah suatu badan yang dapat memiliki hak-hak dan kewajiban-kewajiban untuk melakukan suatu perbuatan seperti manusia, memiliki kekayaan sendiri, dan digugat dan menggugat di depan pengadilan. ${ }^{1}$

Korporasi sebagai badan hukum memiliki beberapa ciri substantif yang melekat pada dirinya, yakni: ${ }^{2}$

\section{Terbatasnya Tanggung Jawab}

Pada dasarnya, para pendiri atau pemegang saham atau anggota suatu korporasi tidak bertanggungjawab secara pribadi terhadap kerugian atau utang korporasi. Jika badan usaha itu adalah PT, maka tanggung jawab pemegang saham hanya sebatas jumlah maksimum nominal saham yang ia kuasai. Selebihnya, ia tidak bertanggungjawab.

\section{Perpetual Succession}

Sebagai sebuah korporasi yang eksis atas haknya sendiri, perubahan keanggotaan tidak memiliki akibat atas status atau eksistensinya. Bahkan, dalam konteks PT, pemegang saham dapat mengalihkan saham yang ia miliki kepada pihak ketiga. Pengalihan tidak menimbulkan masalah kelangsungan perseroan yang bersangkutan. Bahkan bagi PT yang masuk dalam kategori Terbuka dan sahamnya terdaftar di suatu bursa efek (listed), terdapat kebebasan untuk mengalihkan saham tersebut.

\footnotetext{
${ }^{1}$ Chidir Ali, Badan Hukum, Alumni, Bandung, 1987, hlm 19.

${ }^{2}$ Perhatikan David Kelly, et.al, Business Law, Cavendish Publishing Limited, London, 2002, hlm $343-345$.
} 


\section{Memiliki Kekayaan Sendiri}

Semua kekayaan yang ada dimiliki oleh badan itu sendiri, tidak oleh pemilik, oleh anggota atau pemegang saham. Ini adalah suatu kelebihan utama badan hukum. Dengan demikian, kepemilikan kekayaan tidak didasarkan pada anggota atau pemegang saham.

\section{Memiliki Kewenangan Kontraktual serta Dapat Menuntut dan Dapat Dituntut atas Nama Dirinya Sendiri}

Badan hukum sebagai subjek hukum diperlakukan seperti manusia yang memiliki kewenangan kontraktual. Badan itu dapat mengadakan hubungan kontraktual atas nama dirinya sendiri. Sebagai subjek hukum, badan hukum dapat dituntut dan menuntut di hadapan pengadilan.

Nindyo Pramono ${ }^{3}$ menyatakan bahwa filosofi pendirian badan hukum adalah bahwa dengan kematian pendirinya, harta kekayaan badan hukum tersebut diharapkan masih dapat bermanfaat bagi orang lain. Oleh karena itu, hukum menciptakan suatu kreasi "sesuatu" yang oleh hukum kemudian dianggap atau diakui sebagai subjek mandiri seperti halnya orang (natuurlijk persoon atau natural person). Kemudian "sesuatu" itu oleh ilmu hukum disebut sebagai badan hukum (rechtspersoon atau legal person). Agar badan hukum itu dapat bertindak seperti halnya orang alamiah, maka diperlukan organ sebagai alat bagi badan hukum itu untuk menjalin hubungan hukum dengan pihak ketiga.

Agar badan hukum dapat berinteraksi dalam pergaulan hukum seperti membuat perjanjian, melakukan kegiatan usaha tertentu diperlukan modal. Modal awal badan hukum itu berasal dari kekayaan pendiri yang dipisahkan. Modal awal itu menjadi kekayaan badan hukum, terlepas dari kekayaan pendiri. Oleh karena itu, salah satu ciri utama suatu badan hukum seperti PT (termasuk PT Persero) adalah kekayaan yang terpisah itu, yaitu kekayaan terpisah kekayaan pribadi pendiri badan hukum itu. ${ }^{4}$

${ }^{3}$ Nindyo Pramono, "Kekayaan Negara Yang Dipisahkan Menurut UU No. 19 Tahun 2003 tentang BUMN", dalam Sri Rejeki Hartono, et.al, ed, Permasalahan Seputar Hukum Bisnis: Persembahan kepada Sang Maha Guru, Tanpa Penerbit, Jogjakarta, 2006, hlm 142.

${ }^{4}$ Ibid. 


\section{Pengertian dan Tujuan Badan Usaha Milik Negara}

Menurut Pasal 1 UU No. 19 Tahun 2003, BUMN adalah badan usaha yang seluruh atau sebagian besar modalnya dimiliki oleh negara melalui penyertaan secara langsung yang berasal dari kekayaan negara yang dipisahkan.

Dari definisi di atas dapat ditarik kesimpulan, ada beberapa unsur yang menjadi suatu perusahaan dapat dikategorikan sebagai BUMN:

1. Badan usaha atau perusahaan;

2. Modal badan usaha tersebut seluruhnya atau sebagian besar dimiliki oleh negara. Jika modal tersebut tidak seluruhnya dikuasai negara, maka agar tetap dikategorikan sebagai BUMN, maka negara minimum menguasai $51 \%$ modal tersebut.

3. Di dalam usaha tersebut, negara melakukan penyertaan secara langsung;

Mengingat di sini ada penyertaan langsung, maka negara terlibat dalam menanggung risiko untung dan ruginya perusahaan. Menurut Penjelasan Pasal 4 ayat (3) UU No. 19 tahun 2003, pemisahan kekayaan negara untuk dijadikan penyertaan modal negara ke dalam BUMN hanya dapat dilakukan dengan cara penyertaan langsung negara ke BUMN, sehingga setiap penyertaan tersebut harus ditetapkan dengan Peraturan Pemerintah (PP).

4. Modal penyertaan tersebut berasal dari kekayaan negara yang dipisahkan.

Kekayaan yang dipisahkan di sini adalah pemisahan kekayaan negara dari Anggaran Pendapatan dan Belanja Negara (APBN) untuk dijadikan penyertaan modal negara pada BUMN untuk dijadikan modal BUMN. Setelah itu selanjutnya pembinaan dan pengelolaannya tidak lagi didasarkan pada sistem $\mathrm{APBN}$, namun pembinaan dan pengelolaannya pada prinsip-prinsip perusahaan yang sehat. ${ }^{6}$

Suatu badan usaha dapat dikategorikan sebagai BUMN harus merupakan perusahaan yang modalnya berasal dari penyertaan langsung dari negara. Jika ada sebuah PT yang didirikan oleh BUMN, ia tidak dapat

\footnotetext{
${ }^{5}$ Oleh karena BUMN merupakan sebuah badan usaha perusahaan, maka sesuai dengan makna perusahaan atau badan, ia harus bertujuan untuk mendapatkan keuntungan atau profit, bukan untuk tujuan sosial. Lebih lanjut lihat Ridwan Khairandy, Pengantar Hukum Dagang, FH UII Press, Jogjakarta, 2006, hlm

${ }^{6}$ Perhatikan Penjelasan Pasal 4 ayat (1) UU No. 19 Tahun 2003.
} 
dikatakan sebagai BUMN, karena penyertaan modalnya bukan berasal dari negara, tetapi dari BUMN. Misalnya PT Pupuk Kalimantan Timur (PT PKT) tidak dapat disebut sebagai BUMN, karena dari Anggaran Dasar PT tersebut, terlihat bahwa modal perseroan berasal dari penyertaan PT Pupuk Sriwijaya (Persero) dan koperasi karyawan.

Dalam putusan perkara korupsi Direktur Utama PT PKT, Omay K Wiriatmadja, Pengadilan Negeri Jakarta Selatan berpendapat, bahwa PT PKT bukan BUMN. Hal ini didasarkan pada fakta bahwa saham PT PKT tidak dimiliki oleh pemerintah. 99,99 \% saham PT PKT dimiliki oleh PT Pupuk Sriwijaya (Persero). Penyertaan modal PT Pupuk Sriwijaya tidak dapat dikategorikan sebagai penyertaan langsung negara pada PT PKT. Penyertaan tersebut tidak berasal dari APBN.?

UU No. 19 Tahun 2003 secara tegas menyebut bahwa modal BUMN adalah penyertaan langsung dari kekayaan negara yang dipisahkan. Dengan pemisahan ini, maka begitu negara melakukan penyertaan di perusahaan tersebut, penyertaan tersebut demi hukum menjadi kekayaan badan usaha. Pemisahan kekayaan ini merupakan konsekuensi hukum bagi sebuah badan hukum. Dengan demikian, secara yuridis modal tadi sudah menjadi kekayaan perusahaan, bukan kekayaan negara lagi.

Penyertaan modal negara dalam rangka pendirian atau penyertaan pada BUMN menurut Pasal 4 jo Penjelasan Pasal 4 ayat (2) Huruf b UU No. 19 Tahun 2003, bersumber dari:

\section{a. Anggaran Pendapatan dan Belanja Negara;}

Termasuk dalam APBN yaitu meliputi proyek-proyek APBN yang dikelola oleh BUMN dan/atau piutang negara pada BUMN yang dijadikan sebagai penyertaan modal.

\section{b. Kapitalisasi cadangan;}

Kapitalisasi cadangan ini adalah penambahan modal disetor yang berasal dari cadangan.

\section{c. Sumber lainnya}

Termasuk dalam kategori sumber lainnya ini antara lain keuntungan revaluasi aset.

${ }^{7}$ Lihat Kompas, Sabtu 24 Februari 2007. 
Pasal 2 ayat (1) UU No. 19 Tahun 2003 menentukan bahwa maksud dan tujuan didirikannya BUMN adalah: 1. memberikan sumbangan bagi perkembangan perekonomian nasional pada umumnya dan penerimaan negara pada khususnya; Di sini BUMN diharapkan dapat meningkatkan mutu pelayanan pada masyarakat sekaligus memberikan konstribusi dalam meningkatkan pertumbuhan ekonomi nasional dan membantu penerimaan keuangan negara. 2. mengejar keuntungan. Menurut Penjelasan Pasal 1 ayat (1) huruf a, meskipun maksud dan tujuan Persero adalah untuk mengejar keuntungan, namun dalam hal-hal tertentu untuk melakukan pelayanan umum, Persero dapat diberikan tugas khusus dengan memperhatikan prinsip-prinsip pengelolaan perusahaan yang sehat. Dengan demikian, penugasan pemerintah harus disertai dengan pembiayaannya (kompensasi) berdasarkan perhitungan bisnis atau komersial, sedangkan untuk Perum yang tujuannya menyediakan barang dan jasa untuk kepentingan umum, dalam pelaksanaannya harus memperhatikan prinsip-prinsip pengelolaan perusahaan yang baik.; 3 . menyelenggarakan kemanfaatan umum berupa penyediaan barang dan/ atau jasa yang bermutu tinggi dan memadai bagi pemenuhan hajat hidup orang banyak; Dengan maksud dan tujuan seperti ini, setiap usaha BUMN, baik barang maupun jasa, dapat memenuhi kebutuhan masyarakat.; 4 . menjadi perintis kegiatan-kegiatan yang belum dapat dilaksanakan oleh sektor swasta dan koperasi; dan turut aktif memberikan bimbingan dan bantuan kepada pengusaha golongan ekonomi lemah, koperasi, dan masyarakat.

Menurut Penjelasan Pasal 1 ayat (1) huruf d, kegiatan perintisan merupakan suatu kegiatan usaha untuk menyediakan barang dan/atau jasa yang dibutuhkan oleh masyarakat, namun kegiatan tersebut belum dapat dilakukan oleh swasta dan koperasi karena secara komersial tidak menguntungkan. Oleh karena itu, tugas tersebut dapat dilakukan melalui penugasan kepada BUMN.

Dalam hal adanya kebutuhan masyarakat luas yang mendesak, pemerintah dapat pula menugasi suatu BUMN yang mempunyai fungsi pelayanan kemanfaatan umum untuk melaksanakan program kemitraan dengan pengusaha golongan ekonomi lemah.

\section{Perusahaan Perseroan}

Menurut Pasal 1 Angka 1 UU No. 19 Tahun 2003, Perusahaan Perseroan (Persero) adalah BUMN yang berbentuk perseroan terbatas yang 
modalnya terbagi dalam saham yang seluruhnya atau paling sedikit $51 \%$ (lima puluh satu persen) sahamnya dimiliki negara Republik Indonesia yang tujuannya mengejar keuntungan.

Berdasarkan definisi atas, dapat ditarik unsur-unsur yang melekat di dalam Persero, yakni: 1) Persero adalah badan usaha; 2) Persero adalah Perseroan Terbatas; Mengingat Persero adalah PT, pendiriannya dan pengelolaan Persero juga harus tunduk kepada UU No. 1 Tahun 1995, dengan beberapa pengecualian. Pasal 3 dan Penjelasan Pasal 3 UU No 19 Tahun 2003 menyebutkan bahwa BUMN, dalam hal ini Persero tunduk kepada UU No. 1 Tahun 1995 termasuk perubahannya (jika ada) dan peraturan pelaksanaan. Salah satu pengecualian ketentuan UU No. 1 Tahun 1995 terhadap Persero adalah penyimpangan terhadap ketentuan jumlah pemegang saham. UU No. 1 Tahun 1995 mensyaratkan minimal ada dua orang pemegang saham. Ketentuan ini dikecualikan terhadap Persero, karena di dalam Persero adakalanya negara memegang atau menguasai 100 \% (seratus persen) saham Persero; 3) Modalnya terbagi dalam saham; Negara menguasai $100 \%$ atau paling sedikit $51 \%$ saham perusahaan yang bersangkutan. Dalam kasus privatisasi “PT Indosat (Persero) Tbk", negara melepaskan mayoritas kepemilikan saham Persero tersebut kepada pihak swasta asing. Konsekuensinya, Persero tersebut telah menjadi perusahaan swasta atau PT biasa, sehingga perusahaan tersebut menjadi PT Indosat Tbk.; 4) Tujuan didirikannya Persero adalah untuk mengejar keuntungan.Persero dapat berbentuk Persero (Tertutup) dan Persero Terbuka. Persero Terbuka menurut Pasal 1 Angka 3 UU No. 19 Tahun 2003 adalah Persero yang modal dan jumlah pemegang sahamnya memenuhi kriteria tertentu atau Persero yang melakukan penawaran umum sesuai dengan peraturan perundang-undangan yang berlaku. Jadi, Persero dapat terjadi dari kemungkinan. Pertama, Persero tersebut memiliki modal dan jumlah pemegang tertentu yang diisyaratkan peraturan perundang-undangan tertentu. Menurut Pasal 1 Angka 22 UU No. 8 Tahun 1995 tentang Pasar Modal, suatu perusahaan dapat disebut sebagai perusahaan publik (terbuka) bilamana pemegang sahamnya paling sedikit berjumlah 300 (tiga ratus) pemegang saham dan perusahaan tersebut memiliki modal yang disetor sekurang-kurangnya $\mathrm{Rp}$ 3.000.000.000, 00 (tiga milyar rupiah) atau suatu jumlah pemegang saham dan modal disetor yang ditetapkan dengan Peraturan Pemerintah. Kedua, Persero telah melakukan penawaran umum di pasar modal (go public). Di Indonesia, Persero yang masuk kategori ini diantaranya PT Bank Rakyat 
Indonesia (Persero) Tbk, PT Telekomunikasi Indonesia (Persero) Tbk, dan PT Bank Mandiri (Persero) Tbk.

Persero (tertutup) adalah Persero yang tidak termasuk dalam kategori Persero terbuka. Persero yang demikian ini antara lain PT Pertamina (Persero).

\section{Pemisahan Kekayaan Negara dalam Perusahaan Perseroan}

Dari penjelasan di atas secara jelas terlihat Persero adalah PT. Walaupun ada unsur negara di dalam perusahaan tersebut, tetapi oleh karena badan usaha ini adalah PT, maka badan usaha tersebut harus tunduk kepada UU No. 1 Tahun 1995 yang menjadi dasar substantif pengaturan eksistensi PT.

PT oleh hukum dipandang memiliki kedudukan mandiri terlepas dari orang atau badan hukum lain dari orang yang mendirikannya. Di satu pihak PT merupakan wadah yang menghimpun orang-orang yang mengadakan kerjasama dalam PT, tetapi di lain pihak segala perbuatan yang dilakukan dalam rangka kerjasama dalam PT itu oleh hukum dipandang semata-mata sebagai perbuatan badan itu sendiri. Oleh karena itu, segala keuntungan yang diperoleh dipandang sebagai hak dan harta kekayaan badan itu sendiri. Demikian pula sebaliknya, jika terjadi suatu utang atau kerugian dianggap menjadi beban PT sendiri yang dibayarkan dari harta kekayaan PT. ${ }^{8}$

Penyetoran modal pada saat pendirian maupun pada saat penambahan modal PT dalam bentuk saham merupakan suatu penyertaan. Suatu penyertaan adalah keikutsertaan seseorang mengambil bagian dalam suatu badan hukum. Penyertaan itu diwujudkan melalui lembaga saham. ${ }^{9}$

Wujud penyertaan itu adalah penyetoran sejumlah nilai nominal saham yang telah ditentukan dalam anggaran dasar. Penyetoran atas saham itu sendiri menurut Pasal 27 ayat (1) UU No. 1 Tahun 1995 dapat berwujud uang atau bentuk lainnya.

Secara yuridis, modal yang disertakan ke dalam perseroan bukan lagi menjadi kekayaan orang menyertakan modal, tetapi menjadi kekayaan perseroan itu sendiri. Di sini terjadi pemisahan kekayaan antara kekayaan

\footnotetext{
${ }^{8}$ Rudhi Prasetya, Kedudukan Mandiri Perseroan Terbatas Disertai Dengan Ulasan Menurut Undang-Undang No. 1 Tahun 1995, Alumni, Bandung, 1995, hlm 9.

${ }^{9}$ Ibid., hlm 14.
} 
pemegang saham dan perseroan. Dengan karakteristik yang demikian, tanggung jawab pemegang saham atas kerugian atau utang perseroan juga terbatas. Utang atau kerugian tersebut semata-mata dibayar secukupnya dari harta kekayaan yang tersedia dalam perseroan.

Dengan konsep yang demikian itu, maka ketika negara menyertakan modalnya dalam bentuk saham ke dalam Persero dari kekayaan negara yang dipisahkan, demi hukum kekayaan itu menjadi kekayaan Persero. Tidak lagi menjadi kekayaan negara. Konsekuensinya, segala kekayaan yang didapat baik melalui penyertaan negara maupun yang diperoleh dari kegiatan bisnis Persero, demi hukum menjadi kekayaan Persero itu sendiri.

Persoalan kemudian muncul jika konsep tersebut dikaitkan dengan pengertian keuangan negara dan dikaitkan pula dengan praktik tuduhan dan sanksi pidana korupsi yang dikenakan terhadap tindakan direksi Persero dalam menjalankan transaksi bisnis yang didalilkan dapat merugikan keuangan negara.

Menurut Erman Rajagukguk, ${ }^{10}$ sebenarnya tidak ada yang salah dengan perumusan mengenai keuangan negara. Dalam Penjelasan UU No. 31 Tahun 1999 tentang Tindak Pidana Korupsi yang menyatakan bahwa keuangan negara yang dimaksud adalah seluruh kekayaan negara dalam bentuk apapun, yang dipisahkan atau yang tidak dipisahkan, termasuk di dalamnya segala bagian kekayaan negara dan segala hak yang timbul karena: a. berada dalam penguasaan, pengurusan, dan pertanggungjawaban pejabat lembaga negara, baik di tingkat pusat maupun di daerah; b. berada dalam penguasaan, pengurusan, dan pertanggungjawaban Badan Usaha Miliki Negara/Badan Usaha Milik Daerah, yayasan, badan hukum dan perusahaan yang menyertakan modal pihak ketiga berdasar perjanjian dengan negara".

Kekayaan negara yang dipisahkan dalam Persero secara fisik berbentuk saham yang dipegang oleh negara, bukan harta kekayaan milik Persero itu.

Menurut Pasal 8 UU No. 20 Tahun 2001 tentang Perubahan UU No. 31 Tahun 1999 tentang Tindak Pidana Korupsi menyatakan bahwa seseorang baru dikenakan tindak pidana korupsi bila seseorang dengan

${ }^{10}$ Erman Rajagukguk, Nyanyi Sunyi Kemerdekaan Menuju Indonesia Negara Hukum Demokratis, Fakultas Hukum Universitas Indonesia, Lembaga Studi Hukum dan Ekonomi, Depok, 2006, hlm 386. 
sengaja menggelapkan surat berharga dengan jalan menjual saham tersebut secara melawan hukum yang disimpannya karena jabatannya atau membiarkan saham tersebut diambil atau digelapkan oleh orang lain atau membantu melakukan perbuatan tersebut.

Erman Rajagukguk ${ }^{11}$ menambahkan, dalam kenyataannya sekarang ini tuduhan korupsi juga dikenakan terhadap tindakan Direksi BUMN dalam transaksi-transaksi yang didalilkan dapat merugikan kerugian negara. Dapat dikatakan telah terjadi salah pengertian dan penerapan apa yang dimaksud dengan keuangan negara.

Begitu juga tidak ada yang salah dengan pengertian keuangan negara dalam UU No. 17 Tahun 2003 tentang Keuangan Negara. Pasal 1 Angka 1 UU No. 17 Tahun 2003 menyatakan keuangan negara adalah semua hak dan kewajiban negara yang dapat dinilai dengan uang, serta segala sesuatu baik berupa uang maupun barang yang dapat dijadikan milik negara berhubung dengan pelaksanaan hak dan kewajiban tersebut.

Selanjutnya Pasal 2 UU No. 17 Tahun 2003 menyebutkan bahwa keuangan negara sebagaimana dimaksud Pasal 1 Angka 1 di atas mencakup: (1) hak negara untuk memungut pajak, mengeluarkan dan mengedarkan uang dan melakukan pinjaman; (2) kewajiban negara untuk menyelenggarakan tugas layanan umum pemerintahan negara dan membayar tagihan kepada pihak ketiga; (3) penerimaan negara; (4) pengeluaran negara; (5) penerimaan daerah; (6) pengeluaran daerah; (7) kekayaan negara/kekayaan daerah yang dipisahkan yang dikelola sendiri atau pihak lain berupa surat berharga, piutang, barang, serta hak-hak lain yang dapat dinilai dengan uang, termasuk kekayaan negara yang dipisahkan pada perusahaan negara/perusahaan daerah; (8) kekayaan pihak lain yang dikuasai pemerintah dalam rangka penyelenggaraan tugas pemerintahan dan/atau kepentingan umum; dan (9) kekayaan pihak lain yang diperoleh dengan menggunakan fasilitas yang diberikan pemerintah.

Konsisten dengan konsep pemisahan kekayaan di atas, Erman Rajagukguk juga berpendapat bahwa kekayaan negara yang dipisahkan dalam BUMN dalam lahirnya berbentuk saham yang dimiliki negara, bukan harta kekayaan BUMN tersebut. ${ }^{12}$

Menurut Erman Rajagukguk, ${ }^{13}$ kerancuan mulai terjadi dari Penjelasan UU No. 17 Tahun 2003 berkaitan dengan pengertian dan ruang

\footnotetext{
${ }^{11}$ Ibid

${ }^{12} \mathrm{Ibid}$, hlm 387.

${ }^{13} \mathrm{Ibid}$.
} 
lingkup keuangan negara yang menyatakan:

"Pengertian yang digunakan dalam merumuskan Keuangan Negara adalah dari sisi obyek, subyek, proses, dan tujuan. Dari sisi obyek yang dimaksud dengan Keuangan Negara meliputi semua hak dan kewajiban negara yang dapat dinilai dengan uang, termasuk kebijakan dan kegiatan dalam bidang fiskal, moneter dan pengelolaan kekayaan negara yang dipisahkan, serta segala sesuatu baik berupa uang, maupun berupa barang yang dapat dijadikan milik negara berhubung dengan pelaksanaan hak dan kewajiban tersebut. Dari sisi subyek dimaksud dengan keuangan negara meliputi seluruh obyek sebagaimana tersebut di atas dimiliki negara, dan/atau dikuasai oleh Pemerintah Pusat, Pemerintah Daerah, Perusahaan Negara/daerah, dan badan lain yang ada kaitannya dengan keuangan negara. Dari sisi proses, Keuangan Negara mencakup seluruh rangkaian kegiatan yang berkaitan pengelolaan obyek sebagaimana tersebut di atas mulai dari perumusan kebijakan dan pengambilan keputusan sampai dengan pertanggungjawaban. Dari sisi tujuan, Keuangan Negara meliputi seluruh kebijakan, kegiatan dan hubungan hukum atau penguasaan obyek sebagaimana tersebut di atas dalam rangka pemerintahan negara.

Bidang pengelolaan Keuangan Negara yang demikian luas dapat dikelompokkan dalam sub bidang pengelolaan fiskal, sub bidang pengelolaan moneter, dan sub bidang. Pengelolaan kekayaan negara yang dipisahkan".

Dalam pengamatan Nindyo Pramono, ${ }^{14}$ dari definisi keuangan negara yang dirumuskan kedua undang-undang di atas dapat dilihat adanya definisi keuangan negara yang di dalamnya memasukkan kekayaan negara sebagai bagian keuangan negara, namun kedua undang-undang itu tidak memberikan tolok ukur yang sama tentang unsur-unsur apa dari keuangan negara. UU 31 Tahun 1999 memberikan batasan atau tolok pengertian yang sangat luas yaitu meliputi seluruh kekayaan negara dalam bentuk apapun ..., sedangkan UU No. 17 Tahun 2003 memberikan batasan keuangan negara yang lebih sempit yaitu semua hak dan kewajiban negara yang dapat dinilai dengan sejumlah uang ....

Dari dua definisi itu saja orang dapat berdebat. Jika mengacu kepada UU No. 31 Tahun 1999, keuangan negara berarti seluruh keuangan negara ..., sedangkan jika mengacu kepada UU No. 17 Tahun 2003, keuangan negara berarti hak dan kewajiban Samakah makna hukumnya "seluruh

\footnotetext{
${ }^{14}$ Nindyo Pramono, op.cit., hlm 136.
} 
kekayaan negara" dengan "hak dan kewajiban negara"? Jawabannya pasti beda. Di satu sisi wujudnya atau unsurnya adalah seluruh kekayaan atau dapat diperluas dengan istilah seluruh harta kekayaan negara. Di sisi yang lain wujud atau unsurnya adalah hak dan kewajiban. Jika dikaji lebih lanjut, hak dan kewajiban itu erat kaitannya dengan subjek hukum. Menurut hukum, hanya subjek hukum menyandang hak dan kewajiban. PT (Persero) adalah subjek hukum, karena PT (Persero) adalah badan hukum. Harta kekayaan adalah sesuatu atau objek yang dapat dimiliki atau dikuasai oleh subjek hukum yang menyandang hak dan kewajiban itu. $^{15}$

Dari uraian di atas dapat disimpulkan bahwa UU 31 Tahun 1999 mengartikan keuangan negara dari sudut objeknya, sedangkan UU No. 17 tahun 2003 mengartikan keuangan negara dari subjeknya. Dari sisi ini siapapun yang terlibat dalam pelaksanaan hukum tidak menggunakan pendekatan atau kriteria yang sama, dapat dipastikan dalam pelaksanaannya akan menimbulkan permasalahan. ${ }^{16}$

Erman Rajagukguk ${ }^{17}$ menyatakan, kesalahan terjadi lagi dalam PP No. 14 Tahun 2005 tentang Tata Cara Penghapusan Piutang Negara/ Daerah. Pasal 19 menyatakan bahwa penghapusan secara bersyarat dan penghapusan secara mutlak piutang Perusahaan Negara/Daerah dilakukan sesuai dengan ketentuan peraturan perundang-undangan yang berlaku. Selanjutnya Pasal 20 menyatakan bahwa tata cara dan penghapusan secara bersyarat dan penghapusan secara mutlak atas piutang Perusahaan Negara/Daerah yang pengurusan piutang diserahkan kepada PUPN diatur lebih lanjut dengan Peraturan Menteri Keuangan. Dengan demikian, peraturan ini tidak memisahkan kekayaan BUMN Persero dan kekayaan negara sebagai pemegang saham.

Pemerintah menyadari kesalahan pemikiran tersebut ketika menghadapi kredit bermasalah (non performing loan) PT Bank Rakyat (Persero), PT Bank Negara Indonesia, dan PT Bank Mandiri (Persero).

Ketika pemerintah melalui mengambil inisiatif untuk menghapus Pasal 19 dan 20 PP No. 14 Tahun 2005 Menteri Keuangan menyatakan: "Selanjutnya, pengurusan piutang perusahaan negara/daerah dilakukan berdasarkan UU Perseroan Terbatas dan UU badan Usaha

\footnotetext{
${ }^{15}$ Ibid.

${ }^{16}$ Ibid., hlm 137.

${ }^{17}$ Erman Rajagukguk, op.cit., hlm 388.
} 
Milik Negara. Jadi, disebutkan bahwa aturan yang mengatur bankbank BUMN adalah UU Perseroan Terbatas dan Undang-Undang Badan Usaha Milik Negara."18

Usulan perubahan tersebut sempat mengundang perdebatan di dalam Komisi XI Dewan Perwakilan Rakyat karena dianggap membatalkan Pasal 2 Butir g UU No. 17 tahun 2003 tentang Keuangan negara. Untuk itu kemudian diusulkan untuk meminta fatwa Mahkamah Agung Republik Indonesia. Mahkamah Agung sendiri dalam fatwanya membenarkan alasan Menteri Keuangan di atas.

Akhirnya, pemerintah melalui PP No. 33 Tahun 2006 menghapus Pasal 19 dan Pasal 20 PP 14 Tahun 2005. Selanjutnya Pasal II ayat (1) PP No. 33 Tahun 2006 menentukan pada saat berlakunya PP ini mulai berlaku: a. Pengurusan Piutang Negara/Daerah untuk selanjutnya dilakukan sesuai dengan ketentuan peraturan perundang-undangan yang berlaku di bidang Perseroan Terbatas dan Badan Usaha Milik Negara beserta peraturan pelaksanaannya; b. Pengurusan ...

Dengan ketentuan ini terlihat jelas piutang-piutang BUMN, Persero tidak dapat dikategorikan sebagai piutang negara, tetapi piutang-piutang BUMN sendiri. Oleh karena piutang merupakan bagian kekayaan perseroan, maka keseluruhan kekayaan yang dimiliki BUMN adalah BUMN itu sendiri, bukan kekayaan negara.

Permasalahannya sekarang peraturan perundang-undangan mana yang harus dipakai menyelesaikan permasalahan yang menyangkut keuangan negara dikaitkan kekayaan negara. Kekayaan negara yang dipisahkan dalam BUMN harus diperlakukan sebagai aturan khusus (lex specialis), sehingga berdasar adagium lex specialis derogat legi generale, maka UU No. 19 Tahun 2003 harus menjadi dasar penyelesaiannya. Kemudian dikaitkan dengan waktu pengundangannya atau pemberlakuannya, UU No. 19 Tahun 2003 diundangkan lebih belakangan, maka berdasar adagium lex posteriori derogat legi priori, UU 19 Tahun 2003 harus menjadi dasar hukumnya.

Ada satu hal yang harus diingat, jika aparat penegak hukum masih menganut paham kekayaan BUMN adalah kekayaan negara, negara juga harus bertanggungjawab terhadap seluruh utang yang dimiliki BUMN. APBN akan terkuras untuk membayar utang-utang BUMN yang begitu besar.

\footnotetext{
${ }^{18}$ Ibid., hlm 389 mengutip Media Indonesia, 11 Juli 2006.
} 


\section{Penutup}

Secara yuridis penyertaan negara dalam suatu badan usaha yang berbentuk Persero merupakan kekayaan negara yang dipisahkan. Begitu negara menyertakan kekayaan tersebut, kekayaan itu demi hukum menjadi kekayaan Persero. Persero sebagai badan hukum memiliki kedudukan mandiri. Secara fisik kekayaan negara dalam Persero itu berwujud saham, bukan kekayaan Persero yang bersangkutan.

Upaya hukum yang dapat dilakukan negara terhadap direksi yang karena tindakannya menimbulkan kerugian bagi Persero mestinya tidak dilakukan atas dasar tindak pidana korupsi. Negara sebagai pemegang saham dapat melakukan gugatan perdata terhadap direksi tersebut karena melanggar kewajiban fiduciary duty. Direksi yang bersangkutan dapat pula dituntut secara pidana misalnya atas tuduhan melakukan penggelapan, pemalsuan data atau laporan keuangan, dan tindak pidana perbankan.

\section{Daftar Pustaka}

Chidir Ali, Badan Hukum, Alumni, Bandung, 1987.

Munir Fuady, Doktrin-Doktrin Modern dalam Corporate Law, Eksistensinya dalam Hukum Indonesia, Citra Aditya Bakti, Bandung, 2002.

Sri Rejeki Hartono, et.al, ed, Permasalahan Sekitar Hukum Bisnis: Persembahan kepada Sang Maha Guru, Tanpa Penerbit, Jogjakarta, 2006.

David Kelly, et.al, Business Law, Cavendish Publishing Limited, London, 2002.

Denis Keenan, Smith and Keenan's Company Law, Pearson Longman, Harlow, 2002.

Bambang Kesowo, "Fiduciary Duties Direksi Perseroan Terbatas Menurut Undang-undang No. 1 Tahun 1995", Newsletter, edisi No. 23/VI/ Desember 95.

Ridwan Khairandy, Pengantar Hukum Dagang, FH UII Press, Jogjakarta, 2006.

Rudhi Prasetya, Kedudukan Mandiri Perseroan Terbatas Disertai Dengan Ulasan Menurut Undang-Undang No. 1 Tahun 1995, Alumni, Bandung, 1995.

Erman Rajagukguk, Nyanyi Sunyi Kemerdekaan Menuju Indonesia Negara Hukum Demokratis, Fakultas Hukum Universitas Indonesia, Lembaga Studi Hukum dan Ekonomi, Depok, 2006. 
Angela Scheeman, The law of Corporations, Partnerships, and Sole Proprietorship, Delmar Publisher, Albany, 1997.

Ahmad Yani, dan Gunawan Widjaja, Perseroan Terbatas, Raja Grafindo Persada, Jakarta, 1999.

Kompas, Sabtu 24 Februari 2007. 